University of Nebraska - Lincoln

DigitalCommons@University of Nebraska - Lincoln

\title{
Spillover of functionally important organisms between managed and natural habitats
}

\author{
Eleanor J. Blitzer \\ Cornell University, ejb278@cornell.edu \\ Carsten F. Dormann \\ CaA, carsten.dormann@ufz.de \\ Andrea Holzschuh \\ University of Goettingen, a.holzschuh@agr.uni-goettingen.de \\ Alexandra-Maria Klein \\ Leuphana University of Lüneburg \\ Tatyana A. Rand \\ University of Nebraska-Lincoln, tatyana.rand@ars.usda.gov \\ See next page for additional authors
}

Follow this and additional works at: https://digitalcommons.unl.edu/usdaarsfacpub

Part of the Agricultural Science Commons

\footnotetext{
Blitzer, Eleanor J.; Dormann, Carsten F.; Holzschuh, Andrea; Klein, Alexandra-Maria; Rand, Tatyana A.; and Tscharntke, Teja, "Spillover of functionally important organisms between managed and natural habitats" (2012). Publications from USDA-ARS / UNL Faculty. 835.

https://digitalcommons.unl.edu/usdaarsfacpub/835
}

This Article is brought to you for free and open access by the U.S. Department of Agriculture: Agricultural Research Service, Lincoln, Nebraska at DigitalCommons@University of Nebraska - Lincoln. It has been accepted for inclusion in Publications from USDA-ARS / UNL Faculty by an authorized administrator of DigitalCommons@University of Nebraska - Lincoln. 


\section{Authors}

Eleanor J. Blitzer, Carsten F. Dormann, Andrea Holzschuh, Alexandra-Maria Klein, Tatyana A. Rand, and Teja Tscharntke 
Review

\title{
Spillover of functionally important organisms between managed and natural habitats
}

\author{
Eleanor J. Blitzer ${ }^{\mathrm{a}, *}$, Carsten F. Dormann ${ }^{\mathrm{b}}$, Andrea Holzschuh ${ }^{\mathrm{c}}$, Alexandra-Maria Klein ${ }^{\mathrm{d}}$, \\ Tatyana A. Rand ${ }^{\mathrm{e}}$, Teja Tscharntke ${ }^{\mathrm{c}}$ \\ a Department of Entomology, Cornell University, Ithaca, New York, USA \\ ${ }^{\mathrm{b}}$ CaA, Department of Computational Landscape Ecology Permoserstr. 1504318 Leipzig, Germany \\ ${ }^{c}$ Agroecology, Department of Crop Science, University of Goettingen, Goettingen, Germany \\ d Institute of Ecology, Ecosystem Functions, Leuphana University of Lüneburg, Lüneburg, Germany \\ e USDA-ARS Northern Plains Agricultural Research Lab, Sidney, Montana, USA
}

\section{A R T I C L E I N F O}

\section{Article history:}

Received 26 January 2011

Received in revised form

13 September 2011

Accepted 19 September 2011

Available online 20 November 2011

\section{Keywords:}

Edge effects

Herbivory

Mosaic landscapes

Pollination

Seed dispersal

\begin{abstract}
A B S T R A C T
Land-use intensification has led to a landscape mosaic that juxtaposes human-managed and natural areas. In such human-dominated and heterogeneous landscapes, spillover across habitat types, especially in systems that differ in resource availability, may be an important ecological process structuring communities. While there is much evidence for spillover from natural habitats to managed areas, little attention has been given to flow in the opposite direction. This paper synthesizes studies published to date from five functionally important trophic groups, herbivores, pathogens, pollinators, predators, and seed dispersers, and discusses evidence for spillover from managed to natural systems in all five groups. For each of the five focal groups, studies in the natural to managed direction are common, often with multiple review articles on each subject which document dozens of examples. In contrast, the number of studies which examine movement in the managed to natural direction is generally less than five studies per trophic group. These findings suggest that spillover in the managed to natural direction has been largely underestimated. As habitat modification continues, resulting in increasingly fragmented landscapes, the likelihood and size of any spillover effect will only increase.
\end{abstract}

\section{Contents}

1. Introduction

2. Methods

3. Focal groups......

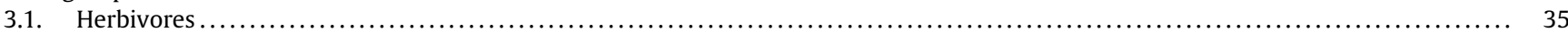

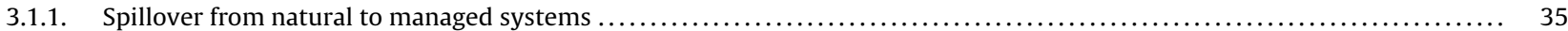

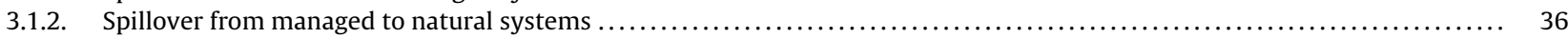

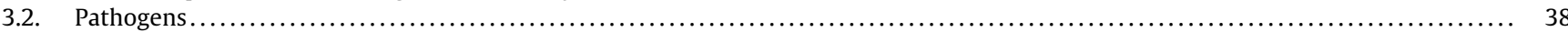

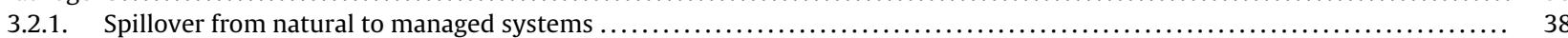

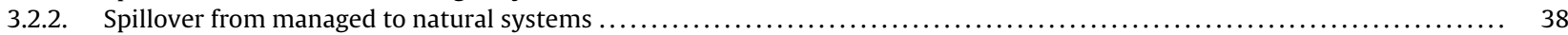

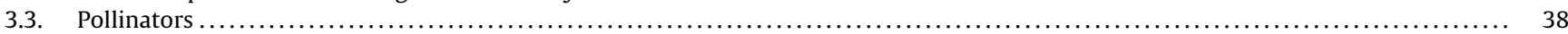

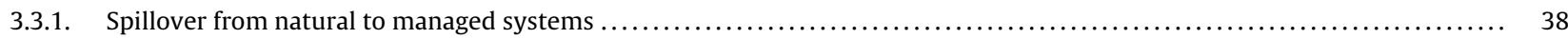

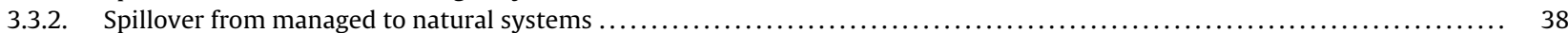

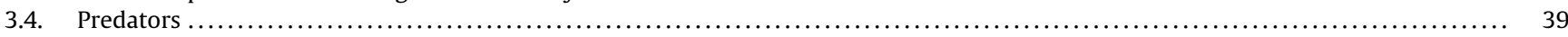

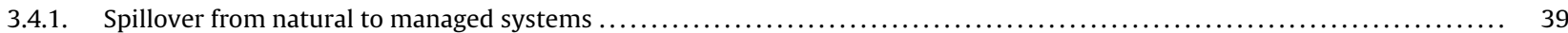

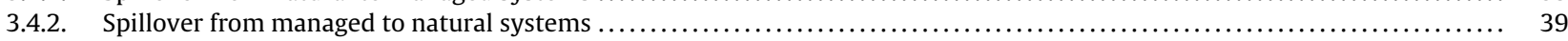

\footnotetext{
* Corresponding author.

E-mail addresses: ejb278@cornell.edu (E.J. Blitzer), carsten.dormann@ufz.de (C.F. Dormann), a.holzschuh@agr.uni-goettingen.de (A. Holzschuh), tatyana.rand@ars.usda.gov (T.A. Rand), ttschar@gwdg.de (T. Tscharntke).
} 


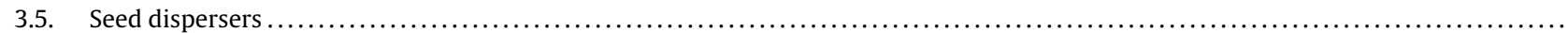

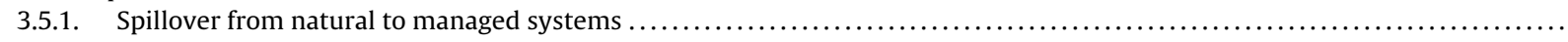

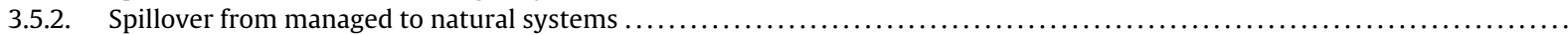

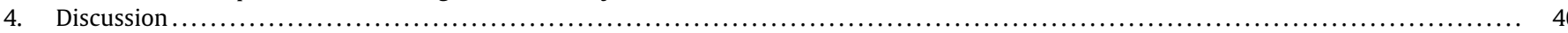

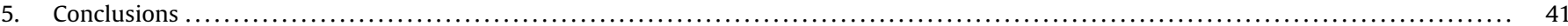

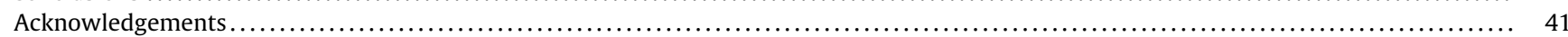

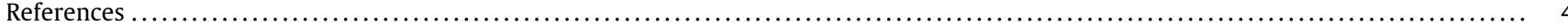

\section{Introduction}

Land-use intensification at habitat and landscape scales over the last century is the major driver of global environmental change in terrestrial ecosystems (Sala et al., 2000). Ecological research focused on landscape effects has increased over the last decade, and, edge effects in particular are likely to become increasingly important as habitat loss increases the extent and types of edges, and thus the probability of dispersal of organisms across habitats. Recent work shows that edge influences on insect communities can penetrate long distances ( $>1 \mathrm{~km}$ ) into adjacent habitats, suggesting that edge effects are likely to have much more pervasive impacts than has been generally appreciated, even for small bodied organisms such as insects (Fahrig, 2003; Ewers and Didham, 2008).

Although ecological coupling via exchanges of energy and organisms among different habitats can have important impacts on a variety of ecosystem functions (McCoy et al., 2009), the mechanisms that determine how different habitats affect one another are still poorly understood. Examples of interconnected habitats include the importance of resource spillover from marine environments in determining community composition in coastal terrestrial systems (Polis et al., 1997) or 'predation shadows', cast by organisms with complex life histories (e.g. dragonflies or frogs), connecting spatially distinct ecosystems (McCoy et al., 2009). The literature on edge effects coupled with work on the food web consequences of cross-boundary subsidies (Polis et al., 1997), provide a key insight underlying our review - that external influences are often important drivers of community structure and dynamics within focal habitats. Here, we make the case that mass movement of organisms between habitats, i.e., across-habitat spillover, often affects trophic interactions in complex landscape mosaics.

This review focuses on functional spillover, defined as movement that results in the function of an organism (e.g. pollination, herbivory) no longer being fulfilled in the habitat where the organism comes from but in the habitat where the organism moves to. Spillover effects can be both positive and negative. We use the example of pollinator spillover between natural grassland areas and managed crops to illustrate this point. At the time of mass flowering of managed crops pollinators moving from natural to managed areas may have a negative effect on native grassland plant species with overlapping flowering periods (reduced seed set due to loss of pollination services), and a positive effect (increased seed set due to increase in pollination services) on managed crops (Fig. 1A). If pollinators gain a supplementary nectar or pollen source in mass flowering managed crops, and at the end of crop flowering events move back into natural grassland areas, spillover can have a positive effect on native grassland species (Fig. 1B).

Spillover of generalist natural enemies, such as predators and herbivores, from managed to natural habitats is likely to be an important process affecting prey populations in adjacent natural systems (Tscharntke et al., 2005; Rand et al., 2006). A previous review of the literature for insect predators reveals that such processes have been understudied, especially when compared with the relatively abundant literature examining flow in the opposite direction, i.e., from natural to agricultural habitats (Rand et al., 2006).
Here, we assess the evidence indicating a potential for spillover effects by reviewing the literature across a broad range of functionally important trophic interactions, including both antagonisms (herbivory, disease, and predation) and mutualisms (pollination, seed dispersal), in both directions across the managed-natural system interface. The objectives of this review are first to summarize the literature examining spillover in the relatively well investigated direction from natural to managed systems; second, to review all studies in the opposite (managed to natural system) direction and discuss the potential functional importance of spillover effects in this direction. This review concludes by weighing the balance of evidence for or against the suggestion from previous work (Rand et al., 2006) that the importance of spillover from managed to adjacent natural habitats has been understudied (Fig. 2).

\section{Methods}

For each focal group in the natural to managed system direction, studies from the most recently published reviews were summarized. To assess the evidence of spillover in the managed to natural direction computer searches using ISI Web of Knowledge and Google Scholar were conducted separately for each focal group. Keywords included: (focal group)+ spillover; movement; mass effects; subsidies; edge effects; or landscape ecology. No limits were imposed with respect to the year of publication or specific journals. Due to the small number of publications explicitly addressing spillover in the managed to natural system direction; a quantitative review was not possible.

From the literature search results, we ultimately selected studies that fell within the scope of the following definitions. We defined spillover as the movement of organisms from one distinct habitat type, or population (in the case of pathogen spillover), to another. The meaning of natural and managed habitats is context and site specific, especially when comparing highly managed European landscapes to North America. For the purposes of this review natural habitats were defined as areas (or populations) that are not intensively managed (e.g. wild dogs, native forests, marshes, and semi-natural habitats such as hay meadows, and woodlots), and managed habitats as agricultural and other intensively managed systems (e.g. domesticated livestock, annually harvested systems dominated by cultivated plants). The focus of this review is primarily on how movement influences function in recipient habitats. The "organisms" in the title were limited to animals and pathogens. Although potentially important, plant spillover, and its influence on function, is beyond the scope of this review.

\section{Focal groups}

\subsection{Herbivores}

\subsubsection{Spillover from natural to managed systems}

Studies documenting herbivore movement from natural areas to adjacent agricultural fields are increasingly common. Much of the older agricultural literature discusses semi-natural habitat as a "reservoir" of pests (Norris and Kogan, 2000). More than 70 families of arthropods known to be potential crop pests are associated with 


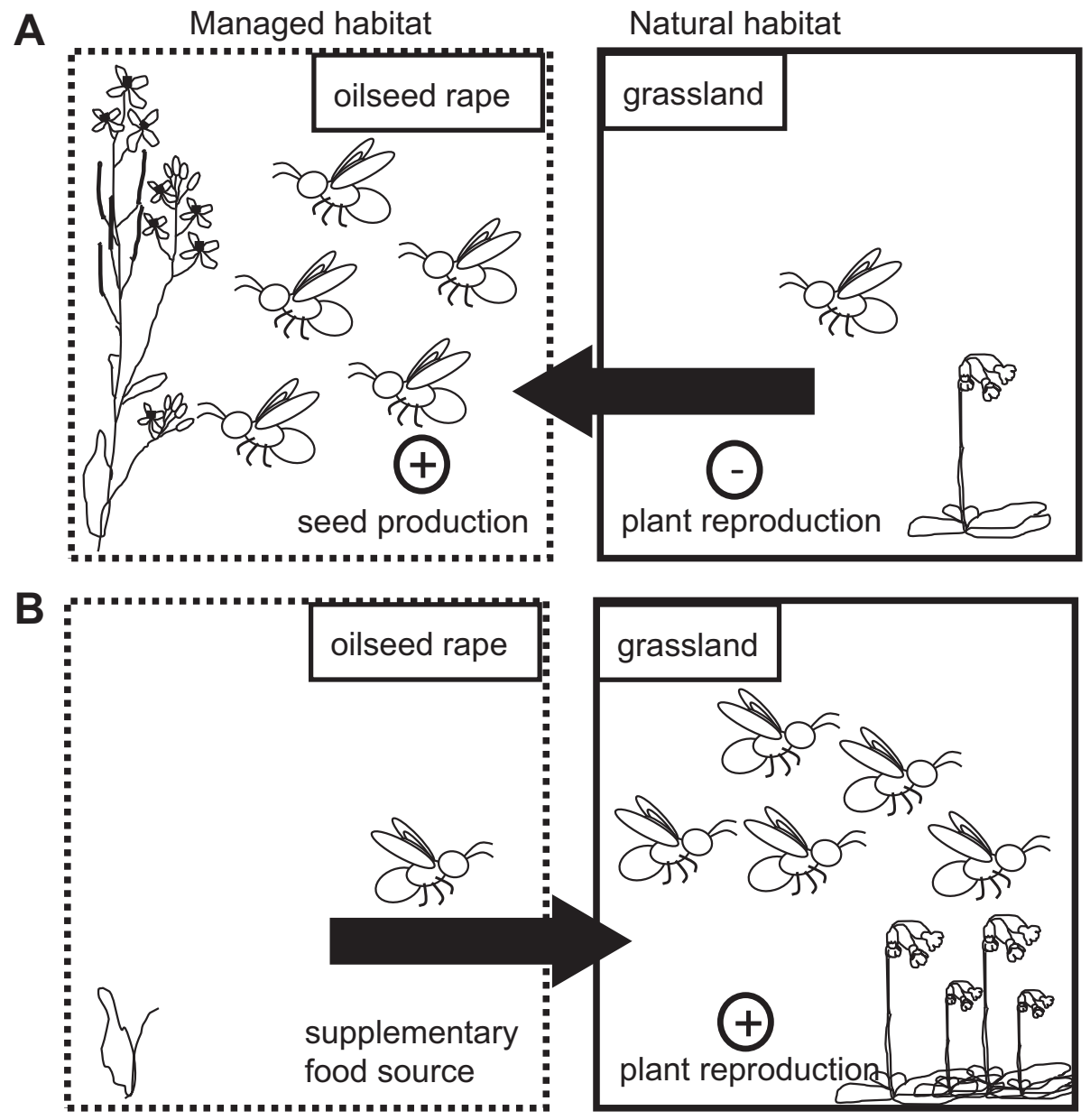

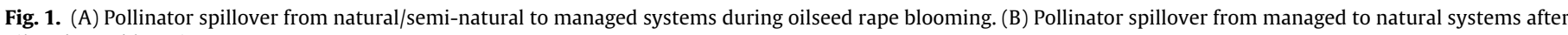
oilseed rape blooming.

non-crop vegetation or "weeds" (Norris and Kogan, 2000). Over 100 studies which investigate the interactions between host weed species and pest arthropods are cited in Norris and Kogan (2000). Field margins, hedgerows, and other natural areas adjacent to managed fields are examples of habitats which host a large variety of pests (Burgess, 1981; Gravesen and Toft, 1987). Herbivores which move from natural areas to agricultural fields and feed on weed species could be considered beneficial (Hatcher and Paul, 2001).

\subsubsection{Spillover from managed to natural systems}

Although currently only a few studies have investigated the movement of herbivores from managed to natural systems, ecologists now recognize the potential detrimental effects of spillover of large populations of herbivores subsidized on agricultural crops to native plants in increasingly small semi-natural habitat fragments. The first study that directly measured this phenomenon investigated the effects of dispersal of adult corn-rootworm beetles, Diabrotica baraberi S., from corn to native sunflower species in endangered tallgrass prairie ecosystems (McKone et al., 2001). The authors consistently found higher densities of $D$. baraberi in native sunflowers in natural prairie patches near the edge of corn fields. Although the abundance of $D$. baraberi was greatest at the corn edge ( $D$. baraberi abundance was reduced by $80 \% 60 \mathrm{~m}$ from corn edge), no part of prairie patches studied were completely free of $D$. baraberi. Pollen feeding by $D$. baraberi was found to reduce seed set of native sunflower species, suggesting that this agricultural pest may interfere with the reproduction of native sunflowers and other late flowering composites.
In Newfoundland, Canada, a more recent example looked at the threat that rare, native, non-agricultural Brassicaceae species face from Plutella xylostella L. (diamondback moth) spillover from agricultural Brassicaceae (Squires et al., 2009). In the study area, typical agricultural host plants such as cabbage occur only in small patches. Thus when $P$. xylostella arrives by wind dispersal from large agricultural Brassicaceae fields further south, (P. xylostella is an annual migrant in Canada during the growing season) their populations are sustained on the rare, native, and non-agricultural Brassicaceae species Braya longii F. and Braya fernaldii A. Plutella xylostella larvae were first seen on $B$. longii and $B$. fernaldii in 1995. In the sites studied, $45-50 \%$ of $B$. longii and B. fernaldii fruit were damaged by $P$. xylostella herbivory, leading to a $60 \%$ decrease in seed set among plants with damaged fruit (Squires et al., 2009). The loss of seeds is of particular importance because $B$. longii and $B$. fernaldii have long-lived seed banks and large plants contribute disproportionately to the seed bank. Plutella xylostella larvae were the only insects observed feeding on $B$. longii and $B$. fernaldii leaves or fruit. $B$. longii mortality has been linked to previous leaf and fruit damage, presumably because $P$. xylostella feeding weakens the plant so that death is more probable in subsequent years. In Mauritius, an introduced pest species of cultivated coffee, Prophantis smaragdina B. (coffee berry moth), has been found feeding on Bertiera zaluzania $\mathrm{G}$. with detrimental effects on the reproductive success of this endangered endemic plant (Kaiser et al., 2008).

Although the three studies discussed above are the only examples found where the functional consequences of spillover were explicitly measured, previous work demonstrating broad host 


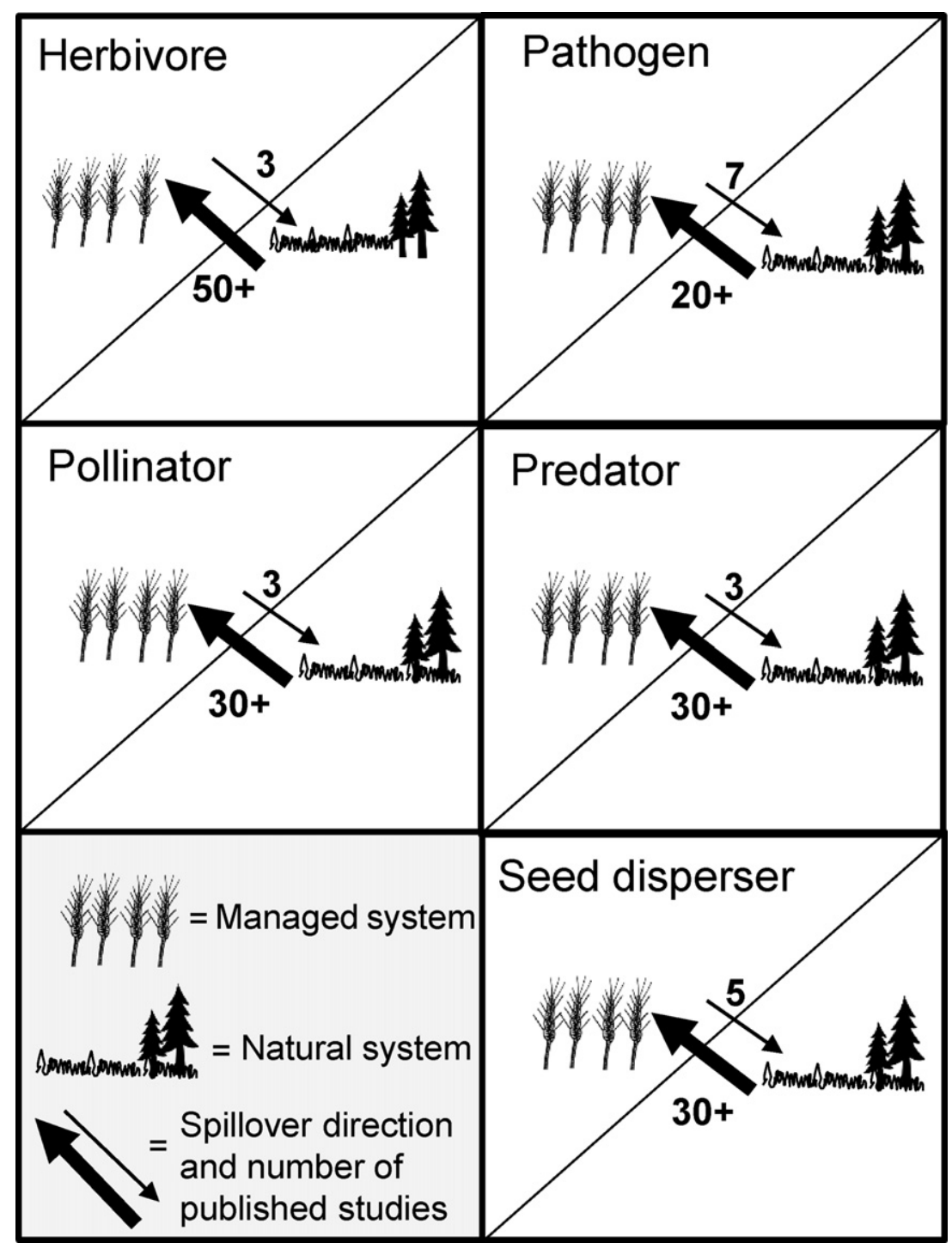

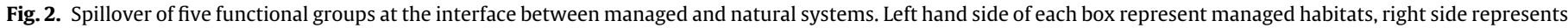

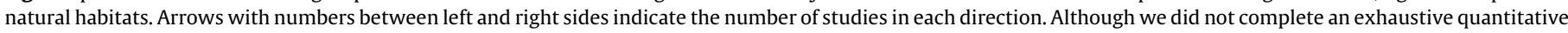

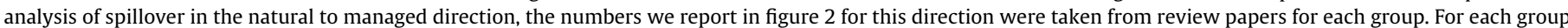

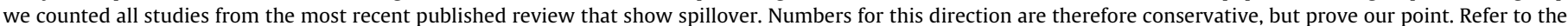
reviews in the text for more detailed discussions of studies in this direction.

ranges in many insects, with host plants present in multiple habitat types, suggests that spillover effects are likely widespread. Examples include aphids, of which at least $10 \%$ show host-plant alternation and movement from non-agricultural to agricultural plant species has been well documented (Mueller and Godfray, 1999) and a number of broadly distributed pest species have been found to feed on native plants in the U.K. (Mueller et al., 1999); grasshoppers which display cyclical movement from grassland into winter wheat fields in the early spring, and then back into native grassland systems once the crop matures (Gillespie and Kemp, 1996); the sunflower moth, Homoeosoma electellum $\mathrm{H}$., which attacks both native and agricultural Helianthus species (Chen and Welter, 2002); and the tarnished plant bug (Lygus rugulipennis P.) which has been recorded on 437 plant species in 57 families (Holopainen and Varis, 1991).

There are also a number of examples of managed herbivores spilling over to affect native plants in the biological control literature. Rhinocyllus conicus F., a Coleopteran thistle specialist introduced to control exotic species, has been found to spillover from its weedy invasive host species onto multiple non-target native species, resulting in increased attack and reduced seed production of native thistles (Louda et al., 1997; Louda, 1998; Rand and Louda, 2004). Cactoblastis cactorum B., introduced for weed biological control in Australia, has since invaded North America and now threatens endangered native cacti (Stiling et al., 2004). Vertebrate herbivores may also be influenced by landscape change. In forest habitats, seed recruitment and survival of native tree species may be affected by spillover of vertebrate seed predators. In Spain large oak forests have been reduced to small fragments within a matrix of agricultural fields. In the fall, after fields are ploughed, small mammals migrate from the barren fields to over-winter in small forest stands and are responsible for high acorn consumption in these areas (Santos and Telleria, 1997). In central Chile, native granivores are more abundant in forest fragments surrounded by managed pine plantations than in the un-fragmented forest areas (Donoso et al., 2004). 


\subsection{Pathogens}

\subsubsection{Spillover from natural to managed systems}

Current epidemiological theory is increasingly concerned with understanding disease ecology in multiple host systems (Power and Mitchell, 2004). Disease movement from semi-natural habitats to domesticated animals and plants is documented (Daszak et al., 2000; Power and Mitchell, 2004). In the epidemiological literature, spillover is explicitly discussed, but it lacks the inherently spatial perspective that we use to define spillover in the other functional groups reviewed. In the case of pathogens, managed systems refer to actively managed host populations, and natural systems to non-managed natural populations. Native plant and animal populations are often cited as reservoirs of disease. Cleaveland et al. (2001) found that $77 \%$ of pathogens infecting mammalian livestock, and $90 \%$ of the pathogens infecting domestic carnivores, were generalists and could attack multiple host species.

The agronomy literature contains many important examples of spontaneous species in natural habitats serving as reservoirs for crop diseases (Wisler and Norris, 2005). In contrast, pathogen spillover can have a positive effect on biological control in agricultural systems when the organisms attacked are pest species rather than the crop plants. Recent advances in conservation biological control have focused on the potential benefits of managing extrafield habitats to promote spillover of beneficial entomopathogens into agricultural fields (Pell et al., 2008).

\subsubsection{Spillover from managed to natural systems}

A recent prominent example of disease movement in the managed to natural direction looks at the spillover of pathogens from domesticated to wild pollinators. Interest in this case is particularly high because of reported declines in bee species and the ecosystem services they provide (Biesmeijer et al., 2006; Potts et al., 2010; Cameron et al., 2011). A number of commercially reared Bombus spp. are used commonly as greenhouse pollinators of at least 20 crop species. (Velthuis and van Doorn, 2006). Infected commercial bumble bees can escape from greenhouses and forage on food sources that they share with wild individuals of the same species or other Bombus spp., infecting the wild species with Crithidia bombi T., an intestinal parasite (Lipa and Triggiani, 1988; Otterstatter and Thomson, 2007). In Canada, evidence for Bombus spp. decline has been quantified, and although it is likely that there are a number of driving factors, pathogen spillover from commercial colonies is thought to be a major culprit (Colla and Packer, 2008). An experiment on the same system examined the prevalence of four pathogens in wild bumble bee populations at locations near and distant to commercial greenhouses in southern Ontario, Canada. Bumble bees collected near commercial greenhouses were more frequently infected by those pathogens capable of being transmitted at flowers ( $C$. bombi and $N$. bombi) than bees collected at sites away from greenhouses (Colla et al., 2006). Scientists in Australia have argued successfully to prevent the importation of Bombus spp. as greenhouse pollinators due to the risk of disease transfer from Bombus to managed and wild Apis species (gov. report, personal comm. S. Cunningham). Australia's high levels of endemic species pose special concerns when thinking about spillover. In Australia, where many agricultural crops rely on high levels of pollination from wild Apis mellifera L., spillover of the invasive Varroa destructor A. from domesticated bee colonies is a concern, but viewed by bee keepers as inevitable (Cook et al., 2007).

Pathogen spillover in vertebrates also provides welldocumented examples of how anthropogenic change can negatively impact wildlife, although pathogen effects on wildlife are under researched (Daszak et al., 2000). Endangered African wild dog and Ethiopian wolf populations have been seriously threatened by rabies, and although we are missing direct evidence, the authors argue that spillover from domestic dogs is almost certainly the cause (Gascoyne et al., 1993; Sillero-Zubiri et al., 1996; Knobel et al., 2008; Lembo et al., 2008). Lembo et al. (2008) adds evidence to the spillover argument by showing that the reservoir of rabies in the Serengeti ecosystem is a complex multi-host community where domestic dogs are the only population essential for persistence, although other carnivores contribute to the reservoir as non-maintenance populations. After a 2000-2002 foot and mouth disease outbreak in domestic livestock in Mongolia, a study in 2001 found the disease in over half of the Mongolian gazelles sampled and authors believe spillover of the virus from domestic animals was the likely cause of the outbreak (Nyamsuren et al., 2006).

Studies of pathogen spillover from domesticated to wild plants are relatively rare. In a review on pathogen spillover, Power and Mitchell (2004) argue that this is due in part to the relative lack of data on pathogens in natural plant populations (Jarosz and Davelos, 1995). In California, the invasion of native grasslands by a variety of Eurasian grasses provides an example of pathogen outbreaks brought by anthropogenic change. Herbarium records document the presence of barley and cereal yellow dwarf viruses, (Luteoviridae $B / C Y D V$ ) in samples from the time period of historical invasion, suggesting that apparent competition mediated by B/CYDV may have facilitated grassland invasion (Malmstrom et al., 2007). In the same system, a recent experimental study found that grazing by vertebrates increases the density of host plants infected with aphid-vectored B/CYDV four-fold, which translates to higher viral prevalence (Borer et al., 2009). The prevalence of some strains of $\mathrm{B} / \mathrm{CYDV}$ in wild grasses is highly dependent on their proximity to crop hosts (Remold and Power, 1995).

Collectively, the pathogen literature provides perhaps the best data documenting the importance of anthropogenically mediated spillover from domesticated to wild plants and animals. Nonetheless, in most cases, we are still lacking quantitative data which unequivocally shows spillover as the process.

\subsection{Pollinators}

\subsubsection{Spillover from natural to managed systems}

Movement of pollinators from natural to managed agricultural landscapes has been documented on six continents across a wide range of habitat and managed landscapes (Liow et al., 2001; Garibaldi et al., 2011). In each of these cases various pollinating insect species are moving from semi-natural land fragments to agricultural fields. Managed and wild pollinating species can provide effective pollination services in many cropping systems, in both temperate and tropical habitats (Klein et al., 2007). Blueberry and watermelon crops are well known examples illustrating the importance of native pollinators. Watermelon is visited by over 30 species of native bees in addition to Apis mellifera in California (Kremen et al., 2002) and at least 47 species in New Jersey (Winfree et al., 2007). Blueberries are effectively pollinated by native bees across a variety of sites (Cook et al., 2007; Isaacs and Kirk, 2010). Examples from tropical regions include rainforest habitats providing sources of pollinating bees for coffee agroecosystems in Indonesia (Klein et al., 2003), Costa Rica (Ricketts, 2004), and Brazil (De Marco and Coelho, 2004); pollinating beetles for atemoya (Blanche and Cunningham, 2005); stingless bees in Longan orchards (Blanche et al., 2006) in Queensland; and ants in mango orchards in South Africa (Carvalheiro et al., 2010).

\subsubsection{Spillover from managed to natural systems}

Although the importance of the movement of pollinators from semi-natural land to more heavily managed agricultural land is well documented in recent reviews (Aizen and Feinsinger, 1994b; Klein et al., 2007; Ricketts et al., 2008; Garibaldi et al., 2011), we are 
still missing an important piece of the puzzle; there are remarkably few studies on the effects of the movement of pollinators in the other direction. It seems likely that pollinator movement through the mosaic landscape of crop and noncrop habitats have an impact on the sexual reproduction of wild plants in embedded natural habitat fragments (Lander et al., 2011). We know that many pollinating species cannot complete their life cycles in agricultural fields. Many bee species use nesting sites in semi-natural habitats and forage for pollen and nectar resources in spatially separated areas, which often include a mixture of disturbed and un-disturbed habitats (Williams and Kremen, 2007). A number of studies show that pollinators visit crop habitats for foraging, but that they must return to natural habitat areas to complete their reproductive cycle because of the frequent disturbance regime in agricultural fields (Hayter and Cresswell, 2006; Greenleaf et al., 2007; Holzschuh et al., 2007; Kremen et al., 2007; Winfree et al., 2007). From these studies we can infer that pollinators are using, and maybe even relying on, resources from crop fields, and then returning to natural habitat fragments. The role of supplementary resources from agricultural habitats in promoting bee populations, and the potential costs and benefits of these resources to wild plant populations have rarely been measured (but see Lander et al., 2011). A recent study from Kenya suggests that bee species-rich farmland might have a positive effect on nearby rain forest fragments by acting as a "pollinator rescue" that supports pollination services inside the natural forest (Hagen and Kraemer, 2010). The authors measured network properties (network size and specialization indices) and bee species turnover at 18 sites in a tropical forest-agriculture mosaic in Western Kenya. The largest networks, highest diversity, and largest abundances of bees were found at the forest edge and in the farmland that hosted higher amounts of flowers and a more homogeneous distribution of resources in space and time when compared to forest sites (Hagen and Kraemer, 2010).

Such spillover effects involving pollinators could result from the interactions of managed honey bees (brought in to provide pollination services to agricultural crops) with wild plants in semi-natural areas adjacent to fields. For example, a study which monitored both wild pollinators and managed honeybee visits on native plants found that the managed honeybees visit 24 of the 43 species of flowering native plants found on the edges of agricultural land (Tuell et al., 2008), possibly contributing to increases in plant fitness. In some systems, honeybee populations from modified habitats may partially compensate for the declines of native pollinators in natural habitat fragments, but this is not always the case (see Garibaldi et al., 2011). For example while the frequency and richness of native pollinators visiting native tree species declined with decreasing fragment size, the frequency of wild honeybee visits increased, such that total visitation frequency varied little with fragmentation (Aizen and Feinsinger, 1994b). Similarly, at least four out of ten self-incompatible native forest plant species studied were heavily visited by honey bees in small habitat fragments, which may have compensated for declining visitation by native pollinators (Aizen and Feinsinger, 1994a). These studies strongly suggest that some native plant species may benefit from the spillover of bees from managed systems into habitat fragments.

Mass flowering of crops could potentially facilitate pollination in semi-natural land if the crops serve as "magnet plants". Recent studies found that mass-flowering of rape increases the growth of bumble bee colonies (Westphal et al., 2009). This concentrates pollinators in the vicinity of mass-flowering agricultural fields, and facilitates spillover into natural areas. The magnet crops might also provide resource subsidies that would allow increases in local pollinator population size the following year. Similarly, a high density of arable fields supporting high weed cover, as often found in organic agriculture, can increase bee populations on a landscape scale, thereby enhancing potential pollination in near-natural fallows (Holzschuh et al., 2008).

Alternatively, flower visitation, pollen transfer, and seed set of wild plants could be adversely affected by competition for pollinators with cultivated crops similar to the competition between native and invasive plants (Lopezaraiza-Mikel et al., 2007; Aizen et al., 2008; Lander et al., 2011). During the typical periods of mass flowering of crops, this competition between natural plants and agricultural crops could lead to a lack of pollination services in natural habitats and could be especially severe for rare plants in conservation areas adjacent to agricultural fields (Steffan-Dewenter and Westphal, 2008; Holzschuh et al., 2011). Furthermore, agricultural habitats may differentially benefit certain pollinator species, such as honey or bumblebees, resulting in competition with native solitary bees which could be more efficient pollinators of some wildland plants, but evidence is scarce (Steffan-Dewenter and Tscharntke, 2000).

Overall, these examples provide clear evidence that pollinators are moving across crop/non-crop interfaces. Agricultural and other managed landscapes surely affect the pollinator-plant interactions of adjacent natural habitats. We therefore need to understand how mass-flowering crops and the introduction of managed pollinators to agricultural fields affect pollinator interactions and pollination services in natural habitats.

\subsection{Predators}

\subsubsection{Spillover from natural to managed systems}

Crop habitats can be hostile environments for many natural enemies and predators of insect herbivores (Kleijn et al., 2001; Meek et al., 2002), which as a result often rely on surrounding natural areas for their persistence. A number of reviews find evidence that such natural and semi-natural areas provide alternative energy sources and host species, as well as over-wintering and nesting habitats, thereby promoting populations of important natural enemy species moving into agricultural fields (Landis et al., 2000; Tscharntke et al., 2005; Bianchi et al., 2006; Rusch et al., 2010). Proximity to habitat edges may also then have an impact on insect herbivores in less productive semi-natural habitats as natural enemies spillover from more productive habitats (Rand et al., 2006; McCoy et al., 2009). Despite many studies looking at the effects of landscape composition and proximity to edges on natural enemy abundance, composition or diversity, comparatively few actually measure the functional implications of such spillover, i.e. effects on pest suppression and crop injury levels (Bianchi et al., 2006; Chaplin Kramer et al., 2011).

\subsubsection{Spillover from managed to natural systems}

Spillover of subsidized natural enemies across managed-tonatural habitat edges is likely to be an important process affecting prey species (Rand et al., 2006). Avian nest predation is one area which has a large body of literature assessing these dynamics. Although there have been no fewer than six review papers (Paton, 1994; Andrén, 1995; Hartley and Hunter, 1998; Soderstrom, 1999; Chalfoun et al., 2002; Lahti, 2009) on the subject in the last two decades, this literature has not succeeded in producing a consensus as to what effect being near a habitat edge has on nest predation. Some nest predation studies mention spillover of predators as the suggested mechanism leading to increased predation pressure near edges, but none have actually quantified this suggestion (Lahti, 2001, 2009). Few studies from other groups have looked into this phenomenon by directly measuring the movement of natural enemies from agricultural to semi-natural areas, and none have attempted to measure the direct and/or indirect impact this movement of predators and parasitoids has on herbivores or plants in these natural habitat fragments. One study measures spider 
activity density in wheat fields and adjacent natural semi-desert in Israel. The authors argue that their data showed a strong preference among sheetweb spiders for agricultural habitat that supports the conclusion that in these semi-desert habitats, sheetweb spiders are moving from wheat fields to adjacent semi-natural desert lands (Pluess et al., 2008). Another study found that wheat-dominated landscapes appear to augment generalist predators (ladybird beetles and spiders) of nettle aphids resulting in dramatically higher natural enemy-prey ratios and reduced aphid density in adjacent nettle patches (Rand and Tscharntke, 2007).

\subsection{Seed dispersers}

\subsubsection{Spillover from natural to managed systems}

In deforested landscapes, seed dispersal is a critical factor for tree succession (Holl, 2002; Marcano-Vega et al., 2002). Low immigration of forest seeds is considered the overriding factor impeding reestablishment of forest in disturbed areas (Da Silva et al., 1996; Duncan and Chapman, 1999; Ingle, 2003). In fragmented, humandominated landscapes, frugivorous birds and bats are the most important biotic seed dispersal vectors, because habitat types such as grassland or early successional vegetation pose less of a barrier to them than to other vectors (Ingle, 2003). For example, in a Philippine montane rainforest frugivorous birds disperse more forest seeds in successional habitats than any of the other studied dispersal species, and seed input declined with distance from source habitat (Ingle, 2003). Seed input into disturbed habitats, such as abandoned pastures, usually steeply declines with distance from source habitats (Howe and Westley, 1997). There is a growing consensus that small patches of forested habitats embedded in a matrix of agricultural land contribute to maintaining biodiversity as well as increasing the efficiency of birds as dispersers in a mosaic landscape (Lozada et al., 2007; Garcia et al., 2010).

\subsubsection{Spillover from managed to natural systems}

We found no studies which explicitly measured spillover of seed dispersers from managed to natural systems, but we discuss studies that highlight the potential for spillover effects in this group. Similar to pollinators subsidized by agricultural crops, seed dispersers may profit from landscape matrix quality (Murphy and Lovett-Doust, 2004). A diversity of land-use systems can have an impact on seed dispersers, especially in the tropics (Garcia and Banuelos, 2003). Examples include studies showing that bats are less abundant in tropical forest fragments surrounded by pastures as compared to fragments embedded in a more structurally complex cocoa and coffee agricultural area (Estrada and Coates-Estrada, 2002). Similarly, in agricultural landscapes of Ecuador, abandoned and managed coffee sites are much more common than forest patches, and they provide a refuge for plant and bird species (Lozada et al., 2007).

In mosaic landscapes, where the vast majority of natural forest has been replaced by agricultural land, agroforestry systems offer birds stepping-stones and thereby reduce reproductive isolation, enhancing tree recruitment (Lozada et al., 2007). Remnant trees in pastures are often used as perches and foraging canopies which can foster seed dispersal from pasture to forest (Galindo-Gonzalez et al., 2000; Laborde et al., 2008; Herrera and Garcia, 2009). Seed dispersal by avian frugivores is more frequent among patches connected by linear habitat patches than in isolated patches (Tewksbury et al., 2002). Other groups of seed dispersers such as carabid beetles or mammals which disperse seeds on their fur are also likely to be important, but we found no studies on spillover from these groups. In human-dominated landscapes, patterns of plant recruitment and plant community succession are strongly influenced by seed spillover across all kinds of habitats, but we lack detailed and quantitative landscape-scale studies that measure spillover.

\section{Discussion}

In all five functional categories reviewed (herbivores, pathogens, pollinators, predators, and seed dispersers), we find direct evidence for influential cross-habitat effects. While the studies are too diverse to be formally used in a quantitative review, the evidence supporting important managed to natural system spillover is far from anecdotal. For each of the five focal groups at least one review paper containing 30 or more studies examines movement in that natural to managed direction. In contrast, the number of studies for each focal group which examine movement in the managed to natural direction is generally less than five studies per group (Fig. 2).

We expect that spillover is more likely in areas with smallscale agriculture, typically found in western Europe and in many parts of the tropics (typically with a mosaic of closely associated crop and noncrop ecosystems), than in large-scale agriculture of North America or Australia - but detailed evidence is missing. Indeed, the examples which document spillover in the managed to natural direction come from diverse geographic areas, biomes, management types, but all have in common that they occur in areas with significant percentages of natural land (Table 1 ). The spillover organisms from the studies in the natural to managed direction are also overwhelmingly ( $>80 \%$ ) generalists (Table 1 ). This finding is not surprising, and again, although there are not enough studies to make conclusions we predict that spillover will be more likely among generalist than specialist organisms.

All of the examples of positive effects of managed on natural habitats are confined to the two mutualisms, pollination and seed dispersal in highly fragmented landscapes. In both cases the available evidence suggests that managed habitats could be important sources of mutualists providing services to wildland plant species in the face of natural habitat loss. We find no studies examining the potential benefits of antagonists spilling over from managed to natural systems, although the possibility for positive interactions does exist. Potentially interesting research along these lines might, for example, address the role of cropping systems as potentially important sources of herbivores spilling over and suppressing weedy plant species in adjacent natural habitats. As we noted earlier, Brassica crops share herbivores with wild Brassica species, which can have detrimental effects on rare native brassicas in Canada (Squires et al., 2009). However, many Brassica species in North America are weedy or invasive, such that similar herbivore spillover could actually be beneficial in these cases. Similar arguments may hold true for other antagonists in crops that are likely to be particularly detrimental to exotic, rather than native, species in natural habitats.

Direct and indirect interactions among trophic groups and across feeding guilds are now increasingly recognized as important in structuring ecological communities (Wootton, 2002; Kaplan and Denno, 2007). Although all the managed-to-natural studies we discuss measure the direct functional effects of spillover of one focal group, indirect interactions among focal groups are likely to be common as well.

It is clear that studies that examine spillover effects from managed to natural systems are rare across the board, and there does seem to be a bias towards studies focused on the negative effects. One explanation for this bias may be that managed systems are often highly disturbed and thought to support only few, disturbance resistant, species. As a consequence they are not generally regarded as meaningful sources of organisms potentially moving over into natural systems. Indonesian homegardens, for example, may include 100-200 crop species and noncrop plants within arable fields and include endangered species (Gabriel et al., 2006). Furthermore, managed systems are often highly productive, thereby providing abundant resources that may be used by non-agricultural species (Westphal et al., 2003). 
Table 1

Details of studies found in the managed to natural direction.

\begin{tabular}{|c|c|c|c|c|}
\hline Study & Focal group & Country & Spillover organism & Specialist/generalist \\
\hline Kaiser et al. (2008) & herbivore & Mauritius & $\begin{array}{l}\text { Prophantis smaragdina (coffee } \\
\text { berry moth) }\end{array}$ & generalist \\
\hline McKone et al. (2001) & herbivore & USA (Kansas) & $\begin{array}{l}\text { Diabrotica virgifera (corn } \\
\text { rootworm) }\end{array}$ & generalist \\
\hline Squires et al. (2009) & herbivore & Canada & $\begin{array}{l}\text { Plutella xylostella (diamond } \\
\text { back moth) }\end{array}$ & generalist \\
\hline Gascoyne et al. (1993) & pathogen & Ethiopia & Rabies virus & generalist \\
\hline Knobel et al. (2008) & pathogen & Ethiopia & Rabies virus & generalist \\
\hline Lembo et al. (2008) & pathogen & Ethiopia & Rabies virus & generalist \\
\hline Lipa and Triggiani (1988) & pathogen & Canada & Crithidia bombi & specialist \\
\hline Nyamsuren et al. (2006) & pathogen & Mongolia & Foot and Mouth disease & generalist \\
\hline Otterstatter and Thomson (2007) & pathogen & Canada & Crithidia bombi & specialist \\
\hline Sillero-Zubiri et al. (1996) & pathogen & Ethiopia & Rabies virus & generalist \\
\hline Aizen and Feinsinger (1994a) & pollinator & Argentina & Apis mellifera & generalist \\
\hline Aizen and Feinsinger, 1994b & pollinator & Argentina & Apis spp. & generalist \\
\hline Holzschuh et al. (2011) & pollinator & Germany & Bombus spp. & generalist \\
\hline Pluess et al. (2008) & predator & Israel & Spiders (94 spp.) & generalist \\
\hline Rand and Tscharntke (2007) & predator & Germany & Spiders and Coccinelld beetles & generalist \\
\hline Rand and Louda (2004) & predator & USA (Nebraska) & Rhinocyllus conicus & specialist \\
\hline Estrada and Coates-Estrada (2002) & seed disperser & Mexico & Bats (50 spp) & generalist \\
\hline Galindo-Gonzalez et al. (2000) & seed disperser & Mexico & Bats (20 spp) & generalist \\
\hline Laborde et al. (2008) & seed disperser & Mexico & Vertebrate frugivores & generalist \\
\hline Herrera and Garcia (2009) & seed disperser & Spain & Birds & generalist \\
\hline Tewksbury et al. (2002) & seed disperser & USA (South Carolina) & Birds & generalist \\
\hline
\end{tabular}

Although many studies support the conservation view that natural systems provide benefits to managed systems, especially as sources of pollinators and biological control agents, cases of natural disservices are also common. The high value humans place on agricultural products likely leads to an immediate reporting and investigation of negative effects of spillover from natural to agricultural systems. This is evidenced by the long tradition of agronomic research looking at wildland plants as potentially important sources of pathogens or herbivorous pests in cropping systems, as well compensation payments to farmers for large predator and herbivore conservation. In contrast, little attention is paid to the wholesale collapse of wildlife populations due to increased contact with managed systems (e.g. wildebeest).

\section{Conclusions}

We find that studies of spillover from managed to natural systems have been generally underrepresented relative to those examining flow in the opposite direction. In particular, the potential positive effects of managed habitats for adjacent natural systems in fragmented landscapes remain largely unstudied. There are numerous examples of studies looking at spillover in the natural to managed direction, perhaps not surprisingly, as this is likely to impact human enterprises.

As humans continue to modify landscapes the likelihood and size of any spillover effect will only increase. Empirical studies are now crucial to provide quantitative evidence in each focal group as well as across disciplines to fully understand the effects of this phenomenon on natural communities.

\section{Acknowledgements}

We appreciate the helpful comments of Stephen Welter and two anonymous referees. Financial support for TT came from the German Science Foundation (DFG) and the German Ministry of Education and Research (BMBF). CFD acknowledges funding by the Helmholtz-Association (VH-NG-247). EJB acknowledges funding from the German Academic Exchange Service (DAAD) and the National Science Foundation (NSF). AH and AMK were supported by the EU-STEP project (Status and Trends of European Pollinators, grant no. 244090-STEP-CP-FP).

\section{References}

Aizen, M.A., Feinsinger, P., 1994a. Forest fragmentation, pollination, and plant reproduction in a chaco dry forest, Argentina. Ecology 75, 330-351.

Aizen, M.A., Feinsinger, P., 1994b. Habitat fragmentation, native insect pollinators, and feral honey bees in Argentine Chaco Serrano. Ecological Applications 4, 378-392.

Aizen, M.A., Morales, C.L., Morales, J.M., 2008. Invasive mutualists erode native pollination webs. PLoS Biology 6, 396-403.

Andrén, H., 1995. Effects of landscape composition on predation rates at habitat edges. Mosaic Landscapes and Ecological Processes 22, 5-255.

Bianchi, F.J.J.A., Booij, C.J.H., Tscharntke, T., 2006. Sustainable pest regulation in agricultural landscapes: a review on landscape composition, biodiversity and natural pest control. Proceedings of the Royal Society Biological Sciences Series B 273, 1715-1727.

Biesmeijer, J.C., Roberts, S.P.M., Reemer, M., Ohlemueller, R., Edwards, M., Peeters, T., Schaffers, A.P., Potts, S.G., Kleukers, R., Thomas, C.D., Settele, J., Kunin, W.E., 2006. Parallel declines in pollinators and insect-pollinated plants in Britain and the Netherlands. Science 313, 351-354.

Blanche, K.R., Cunningham, S.A., 2005. Rain forest provides pollinating beetles for atemoya crops. Journal of Economic Entomology 98, 1193-1201.

Blanche, K.R., Ludwig, J.A., Cunningham, S.A., 2006. Proximity to rainforest enhances pollination and fruit set in orchards. Journal of Applied Ecology 43, 1182-1187.

Borer, E.T., Mitchell, C.E., Power, A.G., Seabloom, E.W., 2009. Consumers indirectly increase infection risk in grassland food webs. Proceedings of the National Academy of Sciences of the United States of America 106, 503-506.

Burgess, L., 1981. Winter sampling to determine overwintering sites and estimate density of adult flea beetle pests of Rape (Coleoptera: Chrysomelidae). Canadian Entomologist 113, 441-447.

Cameron, S.A., Lozier, J.D., Strange, J.P., Koch, J.B., Cordes, N., Solter, L.F., Griswold, T.L., 2011. Patterns of widespread decline in North American bumble bees. Proceedings of the National Academy of Sciences 108, 662-667.

Carvalheiro, L.G., Seymour, C.L., Veldtman, R., Nicolson, S.W., 2010. Pollination services decline with distance from natural habitat even in biodiversity rich areas. Journal of Applied Ecology 47, 810-820.

Chalfoun, A.D., Thompson III, F.R., Ratnaswamy, M.J., 2002. Nest predators and fragmentation: a review and meta-analysis. Conservation Biology 16, 306-318.

Chaplin Kramer, R., O’Rourke, M.E., Blitzer, E.J., Kremen, C., 2011. A meta analysis of crop pest and natural enemy response to landscape complexity. Ecology Letters.

Chen, Y.H., Welter, S.C., 2002. Abundance of a native moth Homoeosoma electellum (Lepidoptera: Pyralidae) and activity of indigenous parasitoids in native and agricultural sunflower habitats. Environmental Entomology 31, 626-636.

Cleaveland, S., Laurenson, M., Taylor, L., 2001. Diseases of humans and their domestic mammals: pathogen characteristics, host range and the risk of emergence. Philosophical Transactions of the Royal Society of London. Series B: Biological Sciences 356, 991.

Colla, S.R., Packer, L., 2008. Evidence for decline in eastern North American bumblebees (Hymenoptera: Apidae), with special focus on Bombus affinis Cresson. Biodiversity and Conservation 17, 1379-1391. 
Colla, S.R., Otterstatter, M.C., Gegear, R.J., Thomson, J.D., 2006. Plight of the bumble bee: pathogen spillover from commercial to wild populations. Biological Conservation 129, 461-467.

Cook, D.C., Thomas, M.B., Cunningham, S.A., Anderson, D.L., De Barro, P.J., 2007. Predicting the economic impact of an invasive species on an ecosystem service. Ecological Applications 17, 1832-1840.

Da Silva, J., Uhl, C., Murray, G., 1996. Plant succession, landscape management, and the ecology of frugivorous birds in abandoned Amazonian pastures. Conservation biology 10, 491-503.

Daszak, P., Cunningham, A.A., Hyatt, A.D., 2000. Emerging infectious diseases of wildlife - threats to biodiversity and human health. Science 287, 443-449.

De Marco, P., Coelho, F., 2004. Services performed by the ecosystem: forest remnants influence agricultural cultures' pollination and production. Biodiversity and Conservation 13, 1245-1255.

Donoso, D.S., Grez, A.A., Simonetti, J.A., 2004. Effects of forest fragmentation on the granivory of differently sized seeds. Biological Conservation 115, 63-70.

Duncan, R., Chapman, C., 1999. Seed dispersal and potential forest succession in abandoned agriculture in tropical Africa. Ecological Applications 9, 998-1008.

Estrada, A., Coates-Estrada, R., 2002. Bats in continuous forest, forest fragments and in an agricultural mosaic habitat-island at Los Tuxtlas, Mexico. Biological Conservation 103, 237-245.

Ewers, R.M., Didham, R.K., 2008. Pervasive impact of large-scale edge effects on a beetle community. Proceedings of the National Academy of Sciences of the United States of America 105, 5426-5429.

Fahrig, L., 2003. Effects of habitat fragmentation on biodiversity. Annual Review of Ecology, Evolution, and Systematics 34, 487-515.

Gabriel, D., Roschewitz, I., Tscharntke, T., Thies, C., 2006. Beta diversity at different spatial scales: plant communities in organic and conventional agriculture. Ecological Applications 16, 2011-2021.

Galindo-Gonzalez, J., Guevara, S., Sosa, V.J., 2000. Bat- and bird-generated seed rains at isolated trees in pastures in a tropical rainforest. Conservation Biology 14 1693-1703.

Garcia, D., Banuelos, M.J., 2003. Matrix matters for seed dispersal - a comment to Jules \& Shahani. Journal of Vegetation Science 14, 931-931.

Garcia, C., Bhagwat, S., Ghazoul, J., Nath, C., Nanaya, K., Kushalappa, C., Raghuramulu, Y., Nasi, R., Vaast, P., 2010. Biodiversity conservation in agricultural landscapes: challenges and opportunities of coffee agroforests in the Western Ghats, India. Conservation Biology 24, 479-488.

Garibaldi, L.A., Steffan Dewenter, I., Kremen, C., Morales, J.M., Bommarco, R., Cunningham, S.A., Carvalheiro, L.G., Chacoff, N.P., Dudenhöffer, J.H., Greenleaf, S.S., 2011. Stability of pollination services decreases with isolation from natural areas despite honey bee visits. Ecology Letters.

Gascoyne, S.C., Laurenson, M.K., Lelo, S., Borner, M., 1993. Rabies in African wild dogs (Lycaon pictus) in the Serengeti region, Tanzania. Journal of Wildlife Diseases 29, 396-402.

Gillespie, R., Kemp, W.P., 1996. Sampling method assessment and quantification of temporal shifts in densities of grasshopper species (Orthoptera: Acrididae) between winter wheat, Triticum aestivum, and adjacent rangeland. Environmental Entomology 25, 559-569.

Gravesen, E., Toft, S., 1987. Grass fields as reservoirs for polyphagous predators. Journal of Applied Entomology 104, 461-473.

Greenleaf, S.S., Williams, N.M., Winfree, R., Kremen, C., 2007. Bee foraging ranges and their relationship to body size. Oecologia 153,589-596.

Hagen, M., Kraemer, M., 2010. Agricultural surroundings support flowervisitor networks in an Afrotropical rain forest. Biological Conservation 143, 1654-1663.

Hartley, M.J., Hunter, M.L., 1998. A meta-analysis of forest cover, edge effects, and artificial nest predation rates. Conservation Biology 12, 465-469.

Hatcher, P., Paul, N.D., 2001. Plant pathogen herbivore interactions and their effects on weeds. In: Biotic Interactions in Plant-Pathogen Associations, pp. 193-225.

Hayter, K.E., Cresswell, J.E., 2006. The influence of pollinator abundance on the dynamics and efficiency of pollination in agricultural Brassica napus: implications for landscape-scale gene dispersal. Journal of Applied Ecology 43, 1196-1202.

Herrera, J.M., Garcia, D., 2009. The role of remnant trees in seed dispersal through the matrix: being alone is not always so sad. Biological Conservation 142, 149-158.

Holl, K., 2002. Do bird perching structures elevate seed rain and seedling establishment in abandoned tropical pasture? Restoration Ecology 6, 253-261.

Holopainen, J., Varis, A., 1991. Host plants of the European tarnished plant bug Lygus rugulipennis Poppius (Het., Miridae). Journal of Applied Entomology 111, 484-498.

Holzschuh, A., Steffan-Dewenter, I., Kleijn, D., Tscharntke, T., 2007. Diversity of flower-visiting bees in cereal fields: effects of farming system, landscape composition and regional context. Journal of Applied Ecology 44, 41-49.

Holzschuh, A., Steffan-Dewenter, I., Tscharntke, T., 2008. Agricultural landscapes with organic crops support higher pollinator diversity. Oikos 117, 354-361.

Holzschuh, A., Dormann, C.F., Tscharntke, T., Steffan-Dewenter, I., 2011. Expansion of mass-flowering crops leads to transient pollinator dilution and reduced wild plant pollination. Proceedings of the Royal Society B: Biological Sciences.

Howe, H., Westley, L., 1997. Ecology of pollination and seed dispersal. In: Crawley, M. (Ed.), Plant Ecology Oxford, pp. 185-216.

Ingle, N., 2003. Seed dispersal by wind, birds, and bats between Philippine montane rainforest and successional vegetation. Oecologia 134, 251-261.

Isaacs, R., Kirk, A.K., 2010. Pollination services provided to small and large highbush blueberry fields by wild and managed bees. Journal of Applied Ecology 47 841-849.
Jarosz, A.M., Davelos, A.L., 1995. Tansley review no. 81: effects of disease in wild plant populations and the evolution of pathogen aggressiveness. New Phytologist 129, 371-387.

Kaiser, C.N., Hansen, D.M., Mueller, C.B., 2008. Exotic pest insects: another perspective on coffee and conservation. Oryx 42, 143-146.

Kaplan, I., Denno, R.F., 2007. Interspecific interactions in phytophagous insects revisited: a quantitative assessment of competition theory. Ecology Letters 10, 977-994.

Kleijn, D., Berendse, F., Smit, R., Gilissen, N., 2001. Agri-environment schemes do not effectively protect biodiversity in Dutch agricultural landscapes. Nature 413 723-725.

Klein, A.-M., Steffan-Dewenter, I., Tscharntke, T., 2003. Pollination of Coffea canephora in relation to local and regional agroforestry management. Journal of Applied Ecology 40, 837-845.

Klein, A.-M., Vaissiere, B.E., Cane, J.H., Steffan-Dewenter, I., Cunningham, S.A., Kremen, C., Tscharntke, T., 2007. Importance of pollinators in changing landscapes for world crops. Proceedings of the Royal Society Biological Sciences Series B 274, 303-313.

Knobel, D.L., Fooks, A.R., Brookes, S.M., Randall, D.A., Williams, S.D., Argaw, K. Shiferaw, F., Tallents, L.A., Laurenson, M.K., 2008. Trapping and vaccination of endangered Ethiopian wolves to control an outbreak of rabies. Journal of Applied Ecology 45, 109-116.

Kremen, C., Williams, N.M., Thorp, R.W., 2002. Crop pollination from native bees at risk from agricultural intensification. Proceedings of the National Academy of Sciences of the United States of America 99, 1681216816.

Kremen, C., Williams, N.M., Aizen, M.A., Gemmill-Herren, B., LeBuhn, G., Minckley, R. Packer, L., Potts, S.G., Roulston, T., Steffan-Dewenter, I., Vazquez, D.P., Winfree, R., Adams, L., Crone, E.E., Greenleaf, S.S., Keitt, T.H., Klein, A.M., Regetz, J., Ricketts, T.H., 2007. Pollination and other ecosystem services produced by mobile organisms: a conceptual framework for the effects of land-use change. Ecology Letters 10, 299-314.

Laborde, J., Guevara, S., Sánchez-Ríos, G., 2008. Tree and shrub seed dispersal in pastures: the importance of rainforest trees outside forest fragments. Ecoscience $15,6-16$.

Lahti, D.C., 2001. The edge effect on nest predation hypothesis after twenty years Biological Conservation 99, 365-374.

Lahti, D.C., 2009. Why we have been unable to generalize about bird nest predation. Animal Conservation 12, 279-281.

Lander, T.A., Bebber, D.P., Choy, C.T., 2011. The circe principle explains how resourcerich land can waylay pollinators in fragmented landscapes. Current Biology 21 1302-1307.

Landis, D.A., Wratten, S.D., Gurr, G.M., 2000. Habitat management to conserve natural enemies of arthropod pests in agriculture. Annual Review of Entomology 45, $175-201$.

Lembo, T., Hampson, K., Haydon, D.T., Craft, M., Dobson, A., Dushoff, J., Ernest, E. Hoare, R., Kaare, M., Mlengeya, T., Mentzel, C., Cleaveland, S., 2008. Exploring reservoir dynamics: a case study of rabies in the Serengeti ecosystem. Journal of Applied Ecology 45, 1246-1257.

Liow, L.H., Sodhi, N.S., Elmqvist, T., 2001. Bee diversity along a disturbance gradient in tropical lowland forests of south-east Asia. Journal of Applied Ecology 38, 180-192.

Lipa, J.J., Triggiani, O., 1988. Crithidia bombi sp. n. a flagellated parasite of a bumble bee Bombus terrestris L. (Hymenoptera, Apidae). Acta Protozoologica 27, 287-290.

Lopezaraiza-Mikel, M.E., Hayes, R.B., Whalley, M.R., Memmott, J., 2007. The impact of an alien plant on a native plant-pollinator network: an experimental approach. Ecology Letters 10, 539-550.

Louda, S.M., 1998. Population growth of Rhinocyllus conicus (Coleoptera: Curculionidae) on two species of native thistles in prairie. Environmental Entomology 27. $834-841$.

Louda, S.M., Kendall, D., Connor, J., Simberloff, D., 1997. Ecological effects of an insect introduced for the biological control of weeds. Science 277, 1088-1090.

Lozada, T., de Koning, G.H.J., Marche, R., Klein, A.-M., Tscharntke, T., 2007. Tree recovery and seed dispersal by birds: comparing forest, agroforestry and abandoned agroforestry in coastal Ecuador. Perspectives in Plant Ecology Evolution and Systematics $8,131-140$

Malmstrom, C.M., Shu, R., Linton, E.W., Newton, L.A., Cook, M.A., 2007. Barley yellow dwarf viruses (BYDVs) preserved in herbarium specimens illuminate historical disease ecology of invasive and native grasses. Journal of Ecology 95 1153-1166.

Marcano-Vega, H., Mitchell Aide, T., Báez, D., 2002. Forest regeneration in abandoned coffee plantations and pastures in the Cordillera Central of Puerto Rico. Plant Ecology 161, 75-87.

McCoy, M.W., Barfield, M., Holt, R.D., 2009. Predator shadows: complex life histories as generators of spatially patterned indirect interactions across ecosystems. Oikos 118, 87-100.

McKone, M., McLauchlan, K.K., Lebrun, E.G., McCall, A.C., 2001. An edge effect caused by adult corn-rootworm beetles on sunflowers in tallgrass prairie remnants. Conservation Biology 15, 1315-1324.

Meek, B., Loxton, D., Sparks, T., Pywell, R., Pickett, H., Nowakowski, M., 2002. The effect of arable field margin composition on invertebrate biodiversity. Biological Conservation 106, 259-271.

Mueller, C., Godfray, H.C.J., 1999. Indirect interactions in aphid-parasitoid communities. Researches on Population Ecology 41, 93-106. 
Mueller, C., Adriaanse, I., Belshaw, R., Godfray, H., 1999. The structure of an aphidparasitoid community. Journal of Animal Ecology 68, 346-370.

Murphy, H., Lovett-Doust, J., 2004. Context and connectivity in plant metapopulations and landscape mosaics: does the matrix matter? Oikos 105, 3-14.

Norris, R., Kogan, M., 2000. Interactions between weeds, arthropod pests, and their natural enemies in managed ecosystems. Weed Science 48, 94-158.

Nyamsuren, D., Joly, D.O., Enkhtuvshin, S., Odonkhuu, D., Olson, K.A., Draisma, M., Karesh, W.B., 2006. Exposure of Mongolian gazelles (Procapra gutturosa) to foot and mouth disease virus. Journal of Wildlife Diseases 42, 154-158.

Otterstatter, M.C., Thomson, J.D., 2007. Contact networks and transmission of an intestinal pathogen in bumble bee (Bombus impatiens) colonies. Oecologia 154, 411-421.

Paton, P.W.C., 1994. The effect of edge on avian nest success: how strong is the evidence? Conservation Biology 8, 17-26.

Pell, J., Baverstock, J., Roy, H., Ware, R., Majerus, M., 2008. Intraguild predation involving Harmonia axyridis: a review of current knowledge and future perspectives. BioControl 53, 147-168.

Pluess, T., Opatovsky, I., Gavish-Regev, E., Lubin, Y., Schmidt, M.H., 2008. Spiders in wheat fields and semi-desert in the Negev (Israel). Journal of Arachnology 36, 368-373.

Polis, G.A., Anderson, W.B., Holt, R.D., 1997. Toward an integration of landscape and food web ecology: the dynamics of spatially subsidized food webs. In: Fautin, D.G. (Ed.), Annual Review of Ecology and Systematics. , pp. 289-316.

Potts, S.G., Biesmeijer, J.C., Kremen, C., Neumann, P., Schweiger, O., Kunin, W.E., 2010. Global pollinator declines: trends, impacts and drivers. Trends in Ecology \& Evolution 25, 345-353.

Power, A.G., Mitchell, C.E., 2004. Pathogen spillover in disease epidemics. American Naturalist 164, S79-S89.

Rand, T.A., Louda, S., 2004. Exotic weed invasion increases the susceptibility of native plants to attack by a biocontrol herbivore. Ecology 85, 1548-1554.

Rand, T.A., Tscharntke, T., 2007. Contrasting effects of natural habitat loss on generalist and specialist aphid natural enemies. Oikos 116, 1353-1362.

Rand, T.A., Tylianakis, J.M., Tscharntke, T., 2006. Spillover edge effects: the dispersal of agriculturally subsidized insect natural enemies into adjacent natural habitats. Ecology Letters 9, 603-614.

Remold, S.K., Power, A.G., 1995. Influences of host and vector specificity on patterns of a virus infection in wild grass hosts. Bulletin of the Ecological Society of America 76, 380.

Ricketts, T.H., 2004. Tropical forest fragments enhance pollinator activity in nearby coffee crops. Conservation Biology 18, 1262-1271.

Ricketts, T.H., Regetz, J., Steffan-Dewenter, I., Cunningham, S.A., Kremen, C., Bogdanski, A., Gemmill-Herren, B., Greenleaf, S.S., Klein, A.M., Mayfield, M.M., Morandin, L.A., Ochieng, A., Viana, B.F., 2008. Landscape effects on crop pollination services: are there general patterns? Ecology Letters 11, 499-515.

Rusch, A., Valantin-Morison, M., Sarthou, J.P., Roger-Estrade, J., 2010. Biological control of insect pests in agroecosystems: effects of crop management, farming systems, and seminatural habitats at the landscape scale: a review. Advances in Agronomy 109, 219-259.

Sala, O.E., Chapin III, F.S., Armesto, J.J., Berlow, E., Bloomfield, J., Dirzo, R., HuberSanwald, E., Huenneke, L.F., Jackson, R.B., Kinzig, A., Leemans, R., Lodge, D.M.,
Mooney, H.A., Oesterheld, M., Poff, N.L., Sykes, M.T., Walker, B.H., Walker, M., Wall, D.H., 2000. Biodiversity: global biodiversity scenarios for the year 2100 . Science 287, 1770-1774.

Santos, T., Telleria, J.L., 1997. Vertebrate predation on Holm Oak, Quercus ilex, acorns in a fragmented habitat: effects on seedling recruitment. Forest Ecology and Management 98, 181-187.

Sillero-Zubiri, C., King, A.A., Macdonald, D.W., 1996. Rabies and mortality in Ethiopian wolves (Canis simensis). Journal of Wildlife Diseases 32, 80-86.

Soderstrom, B., 1999. Artificial nest predation rates in tropical and temperate forests: a review of the effects of edge and nest site. Ecography 22, 455-463.

Squires, S.E., Hermanutz, L., Dixon, P.L., 2009. Agricultural insect pest compromises survival of two endemic Braya (Brassicaceae). Biological Conservation 142, 203-211.

Steffan-Dewenter, I., Tscharntke, T., 2000. Resource overlap and possible competition between honey bees and wild bees in central Europe. Oecologia 122, 288-296.

Steffan-Dewenter, I., Westphal, C., 2008. The interplay of pollinator diversity, pollination services and landscape change. Journal of Applied Ecology 45, 737-741.

Stiling, P., Moon, D., Gordon, D., 2004. Endangered cactus restoration: mitigating the non-target effects of a biological control agent (Cactoblastis cactorum) in Florida. Restoration Ecology 12, 605-610.

Tewksbury, J.J., Levey, D.J., Haddad, N.M., Sargent, S., Orrock, J.L., Weldon, A., Danielson, B.J., Brinkerhoff, J., Damschen, E.I., Townsend, P., 2002. Corridors affect plants, animals, and their interactions in fragmented landscapes. Proceedings of the National Academy of Sciences of the United States of America 99, 12923-12926.

Tscharntke, T., Klein, A.M., Kruess, A., Steffan-Dewenter, I., Thies, C., 2005. Landscape perspectives on agricultural intensification and biodiversity - ecosystem service management. Ecology Letters 8, 857-874.

Tuell, J.K., Fiedler, A.K., Landis, D., Isaacs, R., 2008. Visitation by wild and managed bees (Hymenoptera: Apoidea) to eastern US native plants for use in conservation programs. Environmental Entomology 37, 707-718.

Velthuis, H.H.W., van Doorn, A., 2006. A century of advances in bumblebee domestication and the economic and environmental aspects of its commercialization for pollination. Apidologie 37, 421-451.

Westphal, C., Steffan-Dewenter, I., Tscharntke, T., 2003. Mass flowering crops enhance pollinator densities at a landscape scale. Ecology Letters 6, 961-965.

Westphal, C., Steffan-Dewenter, I., Tscharntke, T., 2009. Mass flowering oilseed rape improves early colony growth but not sexual reproduction of bumblebees. Journal of Applied Ecology 46, 187-193.

Williams, N., Kremen, C., 2007. Resource distributions among habitats determine solitary bee offspring production in a mosaic landscape. Ecological Applications 17, 910-921.

Winfree, R., Williams, N.M., Dushoff, J., Kremen, C., 2007. Native bees provide insurance against ongoing honey bee losses. Ecology Letters 10, $1105-1113$.

Wisler, G., Norris, R., 2005. Interactions between weeds and cultivated plants as related to management of plant pathogens. Weed Science 53, 914-917.

Wootton, J.T., 2002. Indirect effects in complex ecosystems: recent progress and future challenges. Journal of Sea Research 48, 157-172. 